Ks. Norbert WIDOK

(Opole, UO)

\title{
REFLEKSJE O SOBIE SAMYM W KORESPONDENCJI STAREGO GRZEGORZA Z NAZJANZU
}

Grzegorz z Nazjanzu należy do czołowych przedstawicieli teologii wczesnochrześcijańskiej na Wschodzie. Żył w latach 330-390, a więc w tzw. ,złotym" okresie patrystyki, będąc autorem mów, poematów i listów. Jego korespondencja pochodzi z całego dorosłego okresu jego życia, dokładniej-z drugiej jego połowy, trwającej 30 lat, począwszy od przybycia w rodzinne strony po studiach w Atenach ok. 360 roku. Pozostawił po sobie 245 listów, które są nierównomiernie rozłożone na przestrzeni tych lat. Listy Grzegorza są bardzo krótkie, zawierające treść o charakterze osobistym, pełną wyrazów uczuć, utrzymaną często $\mathrm{w}$ tonie poufnych zwierzeń, kierowanych do poszczególnych adresatów.

Cezurą czasową dla określenia „stary Grzegorz”, jak zapowiedziano w tytule, przyjęto 50 rok jego życia, ponieważ w listach napisanych ok. tego roku sam siebie nazywa już starcem. W wieku 50 lat (lub też 51) powrócił w swe rodzinne strony z Konstantynopola, gdzie przez dwa lata pełnił posługę biskupa tego miasta. Przybyciem do Kapadocji w 381 r. rozpoczął etap życia, który bez wątpienia można nazwać schyłkowym. W tym okresie w sposób szczególny - jak to pokazują listy - jeszcze bardziej uwidacznia się jego starość. Okazuje się, że w ostatnim dziesięcioleciu swego życia napisał najwięcej, bo ok. 165 listów (czas pochodzenia niektórych listów nie jest do końca ustalony). Podejmuje w nich różne kwestie, ukazujące jego zaangażowanie w bieżące sprawy kościelne i doktrynalne, przedstawiające jego troskę o innych czy też przyjacielskie relacje $\mathrm{z}$ wieloma osobami.

Kapadocczyk w swoich listach pisze także często o sobie, a przy tym na tematy związane z przemijalnością, a więc także rozmaitymi objawami tego aspektu ludzkiego życia. Lektura jego korespondencji ukazuje kilka stanów jego psychiki i duszy, którymi dzieli się ze swymi bliskimi. W jednym z listów, napisanym w ostatnim roku swego życia, Grzegorz jakby ,jednym tchem" wymienia te stany, które niejednokrotnie stanowiły jego osobistą refleksję wplataną w treść listów wcześniej napisanych. Do Piotra bowiem, prawdopodobnie brata Bazylego, tak napisał: 
„Ale teraz, gdy jest sposobność, pozdrawiam twoją pobożność i proszę: Módl się za mną, zgnębionym starością i chorobą, i lękiem śmiertelnym o życie minione i odlot"'.

Wymienione $\mathrm{w}$ tej wypowiedzi odniesienia do różnych stanów duchowych Nazjanzeńczyka stały się tym samym kluczem do poszukiwania ich opisów w jego korespondencji, a następnie przedstawienia w niniejszym opracowaniu.

1. Świadomość starości. Adresaci listów Grzegorza bardzo często czytali w nich stwierdzenia na temat jego starości i wynikających z niej następstw ${ }^{2}$. Świadomość starości pojawiła się zwłaszcza po śmierci jego serdecznego przyjaciela, Bazylego, który zmarł w wieku 50 lat. Grzegorz był jego rówieśnikiem. List pisany do retora Eudoksjusza w całej swej treści jest lamentem nad własnym życiem:

„Pytasz, jak mi się wiedzie. Bardzo smutno. Bazylego nie mam, Cezariusza nie mam: duchowego brata i cielesnego [...]. Ciało źle się ma, starość na kar$\mathrm{ku}$, trosk gmatwanina, spraw natłoczenie, przyjaciele niewierni, Kościół bez pasterza! Pierzchnęło dobro, wynurza się zło, płyniemy w nocy, znikąd światełka - Chrystus śpi. Co począć? O! Jedno wybawienie z nieszczęść: śmierć”3.

Treść tego listu, pisanego w wieku 50 lat, jest poniekąd streszczeniem duchowej postawy następnej dekady jego życia. Wymienione aspekty tej postawy pojawiają się w każdym prawie liście później napisanym. Obok trosk codziennego życia, a zwłaszcza spraw związanych z ówczesną wspólnotą kościelną, w sposób wyraźny skarży się na starość i słabość cielesną. Grzegorz chętnie lubi podkreślać swą starość. Pisząc do Asteriusza, urzędnika w Kapadocji, prosi go o wstawiennictwo dla swego krewniaka:

„[...] Nikobula miłością otaczam, w którym widzę pielęgniarza w starości

i chorobie, którego mam niby za podporę i kostur mojej bezsilności"’.

Ta wypowiedź to bez wątpienia szczere przyznanie się Grzegorza do swej kondycji życiowej, która nie była do pozazdroszczenia.

Podobnie Helladiusz, jeden z biskupów Kapadocji Drugiej, stał się obok życzeń skierowanych pod jego adresem odbiorcą następujących słów:

\footnotetext{
${ }^{1}$ Epistula 242 (Ad Petrum), PG 37, 384, tłum. J. Stahr, POK 15, Poznań 1933, 286.

${ }^{2}$ Wątek starości w oparciu o teksty Grzegorza z Nazjanzu podejmuje m.in. I. Camellini, Gregorio Nazianzeno, w: Senectus. La vecchiaia nell antichità, ed. U. Mattioli - A. Cacciari V. Neri, vol. 3: Ebraismo e cristianesimo, Bologna 2007, 370-386. Autorka zajmuje się starością w relacjach międzypokoleniowych, zwłaszcza problemem oddawania szacunku starym rodzicom. Sędziwość starszych ludzi powinna być ponadto autorytetem dla młodszych. Autorka opiera się głównie o mowy i poematy, kilkakrotnie tylko odwołuje się do listów, z których relacjonuje kwestię fizycznego cierpienia w starości.

${ }^{3}$ Epistula 80 (Ad Eudoxium rhetorem), PG 37, 153, POK 15, 113.

${ }^{4}$ Epistula 147 (Ad Asterium), PG 37, 252, POK 15, 191-192.
} 
„A jeślibyście mi dali i starość moją pięknie zamknąć, użyczając temu Kościołowi biskupa, którego Duch Święty naznaczy, spełnilibyście dobry uczynek"s.

Treścią tego listu była troska Grzegorza o właściwy wybór biskupa. W tok tych myśli w sposób ironiczny dołączył także refleksję na temat swojej starości. W takim samym tonie Kapadocczyk podkreślał swą starość w listach posłanych do innych biskupów. Do Amfilochiusza napisał: „Tyś starość moją szczodrze pokrzepił"6, a do Nektariusza podobnie: ,[...] raczysz mnie czcić i, jak dziecię ukochane, ojca w starości pocieszać"'. Swą życiową przypadłość raczył też przypomnieć Nemezjuszowi, który był prefektem Kapadocji, prosząc go o opiekę nad sierotami:

„Wiele jest powodów, dlaczego możesz mi życzliwość okazywać: starość, niemoc, wspólność zamiłowań naukowych"8.

Tak ujęta prośba sugeruje, że Grzegorz swą starość i niemoc wykorzystywał jako środek wzbudzający litość, szacunek czy też autorytet w celu wyświadczenia mu żądanej prośby.

W innych listach Grzegorz wręcz nazywa siebie starcem. Z pewną dozą ironii wobec własnej osoby zwraca się do namiestnika Kapadocji, Olimpiusza:

,[...] staliśmy się znowu drugą Kapadocją gdy dzięki tobie byliśmy pierwszą. O innych nie mówię - ale kto będzie pocieszać starego Grzegorza? Kto moją niemoc zażegna zaszczytami, kto doda czci temu, który dla wielu u ciebie miłosierdzie wyjednywał?"'.

Olimpiusz, który złożył swój urząd, był dla Grzegorza autorytetem w rządzeniu i człowiekiem bardzo mu bliskim, pocieszającym go w starości. Jeszcze więcej ironii płynie ze stwierdzenia napisanego przez Grzegorza w liście do Epifaniusza:

„Jeśli oddasz pięknem za nadobne i często to raczysz czynić, to i ze mnie starca - zrobisz może wojownika, nielichszego wcale od Nestora" ${ }^{10}$.

W innym liście, chcąc pełnić rolę pośrednika w sporze powstałym pomiędzy Sacerdosem, zarządcą klasztoru, a Eudocjuszem, mnichem tego klasztoru, napisał do tego ostatniego:

\footnotetext{
${ }^{5}$ Epistula 120 (Ad Helladium), PG 37, 216, POK 15, 163.

${ }^{6}$ Epistula 184 (Ad Amphilochium), PG 37, 301, POK 15, 228.

${ }^{7}$ Epistula 185 (Ad Nectarium), PG 37, 304, POK 15, 229.

${ }^{8}$ Epistula 199 (Ad Nemesium), PG 37, 325, POK 15, 244.

${ }^{9}$ Epistula 154 (Ad Olympium), PG 37, 261, POK 15, 198.

${ }^{10}$ Epistula 239 (Ad Epiphanium), PG 37, 381, POK 15, 284.
} 
„[...] przeto zechciej przybyć do mnie, jako starca mnie uczcić, jako ojca uszanować i obrać mnie na pośrednika w sporze z czcigodnym bratem i współprezbiterem moim Sacerdosem"11.

Ton tej wypowiedzi jest daleki od ironii, a raczej zawarty jest w niej autorytet człowieka starego, który ma pomóc w rozwiązaniu zaistniałego konfliktu.

W powyższych fragmentach listów, oprócz ironii wobec własnej osoby, jest obecne ponadto pogodzenie się z faktem osiagnięcia starości jako etapu dojścia do szczytu ludzkiej dojrzałości. Atrybutem starości, którym Grzegorz chętnie się posługuje, jest jego siwizna. Pisze tak do Olimpiusza:

„I przy siwiźnie człowiek się uczy i nie zawsze, jak widać, na mądrości sędziwego wieku polegać można. Ja, chociażem najlepiej ze wszystkich znał zamysły i bezbożność apolinarystów i widziałem ich nieznośne zuchwalstwo, sądziłem, że cierpliwością ich ugłaskam i nieco zmiękczę"12.

Z jednej strony autor tych słów podkreśla związek starości i mądrości, z drugiej jednak strony jest świadomy, że został pokonany przez przewrotność i zuchwalstwo apolinarystów ${ }^{13}$. Jego cierpliwość, będąca też owocem osiagnięcia mądrości w wieku starczym, nie pomogła.

Siwizna Grzegorza staje się w jego listach także argumentem w prośbach o wstawiennictwo. Prokopiusz, przyjaciel Kapadocczyka, w jednym z listów otrzymał następującą prośbę w sprawie diakona Eugeniusza:

„[...] na moją siwizną, którą, jak wiem, wielu ludzi bogobojnych poważa, okaż tę łaskę, błagam, i mnie i całemu duchowieństwu"14.

Również z tych słów płynie pewność Grzegorza, odnosząca się do powagi siwizny jako oznaki starości. W innych listach prosi nawet o uczczenie swej siwizny w tych ich stwierdzeniach, które dotyczą błagalnych próśb kierowanych do adresatów. Autorytatywny wręcz nakaz otrzymał wymieniony już Olimpiusz w formule „Uczcij mą siwiznę"15 lub też „Uczcij też moją siwiznę"16 w listach o charakterze wstawienniczym ${ }^{17}$. Natomiast w duchowym uniesieniu Grzegorz wymienia swą siwiznę w liście do Tekli, siostry Sacerdosa:

${ }^{11}$ Epistula 216 (Ad Eudocium), PG 37, 353, POK 15, 263.

${ }^{12}$ Epistula 125 (Ad Olympium), PG 37, 217, POK 15, 166.

${ }^{13} \mathrm{O}$ doktrynie Apolinarego zob. E. Mühlenberg, Apollinaris von Laodicea und die origenische Tradition, ZNW 76 (1985) 270-283.

${ }^{14}$ Epistula 129 (Ad Procopium), PG 37, 224, POK 15, 171.

${ }^{15}$ Epistula 142 (Ad Olympium), PG 37, 244, POK 15, 186.

${ }^{16}$ Epistula 141 (Ad Olympium), PG 37, 241, POK 15, 185.

${ }^{17}$ Problematykę zawartą w listach wstawienniczych opracował N. Widok, Postawa Grzegorza z Nazjanzu wobec świeckich w świetle jego listów protekcyjnych, VoxP 22 (2002) t. 42-43, 187-207. 
„[...] mozół mój nie poszedł na marne i że więcej u ciebie znaczę, niż inni, [...] - a to może i tym siwym włosom moim i mozołom dla Boga podjętym się należy"18.

Autor tej wypowiedzi podkreśla swój wkład w budowanie tamtejszej wspólnoty kościelnej, m.in. także poprzez godzenie zwaśnionych stron. Cieszy się z pozytywnego obrotu sprawy, co składa w hołdzie swej mądrości i swym siwym włosom.

W niektórych wypowiedziach siwizna staje się odniesieniem niezwykle autorytarnym, zwłaszcza wówczas, gdy Grzegorz nie jest zadowolony z przebiegu danych spraw. Taki charakter mają słowa napisane do Eustochiusza, sofisty:

„[...] i zaniechajcie słówek i przymówek, jeśli nie dla czego innego, to z czci dla mojej siwizny albo ze znużenia się w tej hańbie"19.

W jeszcze bardziej surowym tonie zwrócił się do Adelfiusza, młodzieńca, który miał czynić postępy duchowe:

„Nie wiem, co się z tobą stało! Co za zamroczenie w twej duszy! Dlaczego hańbisz swój ród? Hańbisz i mój siwy włos i nadzieje, którem na tobie budował"'20.

Te wypowiedzi są dalekie od ironii, natomiast płynie z nich powaga i dostojeństwo dla wieku Grzegorza i jego życiowych doświadczeń.

Z powyższych wypowiedzi wynika, że Grzegorz przyjął do świadomości okres życia, w który wkroczył, że minęły lata młodości, jednak w przekonaniu, że starość cieszy się także różnymi względami ${ }^{21}$.

2. Obecność choroby. Całkiem inaczej jednak dzisiejszy czytelnik przyjmuje zwierzenia Kapadocczyka odnoszące się do choroby i niemocy cielesnej, która go nękała. W nich obecna jest nostalgia za coraz bardziej traconym zdrowiem i tężyzną życia. Po śmierci Bazylego pisze list do jego brata, Grzegorza z Nyssy, niosąc mu słowa pocieszenia. Początek listu jest zwróceniem uwagi na siebie i swój stan zdrowia:

„I to jeszcze spotkało mój utrapiony żywot, żem usłyszał o śmierci Bazylego, o odlocie tej świętej duszy! [...] A ja obok innych rzeczy i tego zostałem pozbawiony wskutek ciagle jeszcze ciężkiej i bardzo niebezpiecznej choroby, bym mógł ucałować jego święte popioły i być przy tobie"22.

\footnotetext{
${ }^{18}$ Epistula 223 (Ad Theclam), PG 37, 368, POK 15, 272.

${ }^{19}$ Epistula 191 (Ad Eustochium), PG 37, 313, POK 15, 236.

${ }^{20}$ Epistula 206 (Ad Adelphium), PG 37, 341, POK 15, 254.

${ }^{21}$ Por. Camellini, Gregorio Nazianzeno, s. 384-386.

${ }^{22}$ Epistula 76 (Ad Gregorium Nyssenum), PG 37, 140, POK 15, 104.
} 
Relacja dotycząca choroby przedstawia się dosyć poważnie, ponieważ Grzegorz cierpiał na nią już od pewnego czasu, i to chorobę ciężką i bardzo niebezpieczną: nie określa jej bliżej, ani nie nazywa. Niestety, nie pozwoliła mu ona na wzięcie udziału w pogrzebie swego najlepszego przyjaciela. Musiała to być bardzo poważna choroba, skoro śmierć jedynego przyjaciela nie okazała się silniejsza, by pokonać trudy podróży.

Bazyli zmarł przed podjęciem przez Grzegorza urzędu biskupiego w Konstantynopolu. Zatem po pewnym czasie musiał poczuć się zdecydowanie lepiej, skoro zdecydował się na przyjęcie posługi pasterskiej w stolicy. Nie miał tam łatwego życia, o czym zaświadcza $\mathrm{w}$ liście pisanym w czasie tej posługi do Gigantiusza, dodając uwagę o stanie zdrowia: „Liche zdrowie i czas zimowy wstrzymują mą ochotę" ${ }^{23}$. List ten jest dowodem tego, że Grzegorz także w Konstantynopolu cierpiał duchowo i cieleśnie. Również zaraz po zakończeniu pełnienia tam pasterskiej działalności, a trwającej bardzo krótko, bo zaledwie 2 lata, znowu pisze o pogorszeniu się zdrowia do Filargiusza, który też jest chory:

„Że nie możemy zobaczyć się z sobą, ta sama bieda i mnie i tobie przeszkadza. Tobie ciało jak dokucza tak dokucza, żeby więcej nie powiedzieć: a ze mną - wiedz - jest bardzo licho"24.

W tym samym czasie inny adresat, Prokopiusz, dowiaduje się o złym stanie zdrowia Grzegorza, który mu napisał:

„Powodzi mi się znośniej niż straceńcom, ale gorzej niż tym, o których Bóg pamięta. Bo i choroba dokucza jeszcze, raczej porządnie doskwiera - a przyjaciele nie przestają dręczyć i wedle sił szkodzić” 25 .

Te wzmianki o stanie zdrowia Grzegorz utrwalił, jak już wspomniano, po przyjeździe z Konstantynopola do Kapadocji.

Wprawdzie rozpoczął się dla niego okres spokojnej starości, jak można by sądzić, tymczasem choroba go nie opuszczała. Pogorszenie się zdrowia z całą pewnością mogło być następstwem odejścia ze stolicy, któremu towarzyszyły przykre chwile. Do swego następcy na urzędzie biskupim, Nektariusza, tak o nich wspomina: „Mnie zaś wymiotło, wyrzuciło jak śmiecie, plewy, jak męty morskie"26. Te słowa świadczą o rozczarowaniu przeszłymi faktami, a więc też o psychicznym przygnębieniu, czego choroba była oczywistą konsekwencją. Jednak po krótkim czasie nastapiła poprawa stanu zdrowia, o czym informuje tego samego adresata, Nektariusza: ,[...] z łaski Bożej wylizałem się z choroby niezgorzej"27. Radość z powrotu do zdrowia nie trwała jednak długo, gdyż w następnym roku (382) znowu skarży się na jego pogorszenie w listach

\footnotetext{
${ }^{23}$ Epistula 100 (Ad Gigantium), PG 37, 173, POK 15, 128.

${ }^{24}$ Epistula 87 (Ad Philargium), PG 37, 160, POK 15, 119.

${ }^{25}$ Epistula 90 (Ad Procopium), PG 37, 164, POK 15, 122.

${ }^{26}$ Epistula 88 (Ad Nectarium), PG 37, 161, POK 15, 120.

${ }^{27}$ Epistula 91 (Ad Nectarium), PG 37, 165, POK 15, 122.
} 
wstawienniczych słanych do Olimpiusza: „Czas lotny, bój groźny - a choroba ciąży i niemal mnie ubezwładnia!" ${ }^{28}$, ciesząc się jego protektoratem, jak to wyznaje w następnym liście: ,[...] skoroś przecież raz myśl powziął pocieszać mą schorzałą sędziwość takimi zaszczytami”29. W podobnym tonie śle listy do Teodora, biskupa Tyany, zapraszając go do siebie: „Winieneś mi, jako choremu troskę, bo jednym z przykazań jest nawiedzanie chorych" 30 , a gdy sam został zaproszony przez Teodora, odpowiada:

„Ale że powietrze jest jeszcze ostre, a choroba nie popuściła - zaklinam, bądź trochę cierpliwy, proś o moje zdrowie"31.

Ten drugi atak choroby, o której tak często wspominał w powyższych listach, był powodem zaniechania krótko trwających obowiązków duszpasterskich w Nazjanzie. Musiała to być poważna utrata zdrowia, skoro Grzegorz nie tylko nie był w stanie podjąć tych obowiązków, ale także nawet odwiedzić swego przyjaciela Prokopiusza, do którego tak pisał:

„Gdyby się ciało ze mną źle nie obchodziło i gdybym nie miał ponurych widoków co do życia samego - to jako coś pierwszego i największego uzyskałbym zobaczenie się z tobą i pobyt u ciebie, [...]. Ponieważ jednak leżę całkowicie spętany niemocą i mimo woli stratny jestem - czynię, co mi pozostaje: zachodzę do ciebie listownie"32.

Słowa tego listu dowodzą, że kondycja zdrowotna Grzegorza była niezwykle słaba, nie pozwalająca mu na wykonywanie służebnych czynności, ani też na utrzymywanie przyjacielskich kontaktów w formie wzajemnych odwiedzin. Kapadocczyk mimo braku takich możliwości szuka innego kontaktu, mianowicie listowego. Stan zdrowia nie pozwolił mu też uczestniczyć w synodzie, jak wynika z listu pisanego do tegoż samego przyjaciela, który ponadto przeczytał w nim kolejną relację o stanie jego zdrowia:

„Teraz zaś nadto ciężka choroba oręduje memu postanowieniu, bo prawie co chwila ostatnie tchnienie wydaję i czuję się do niczego"33.

Zły stan zdrowia stał się dla Grzegorza wybawieniem od wyjazdu na synod, co można wnioskować z pierwszego zdania tego samego listu:

„Jestem, żeby prawdę napisać, tak usposobiony, że unikam wszelkich zebrań biskupów, ponieważ nie widziałem żadnego soboru z pomyślnym końcem"34.

\footnotetext{
${ }^{28}$ Epistula 105 (Ad Olympium), PG 37, 205, POK 15, 154.

${ }^{29}$ Epistula 106 (Ad Olympium), PG 37, 205, POK 15, 155.

${ }^{30}$ Epistula 122 (Ad Theodorum), PG 37, 216, POK 15, 164

${ }^{31}$ Epistula 123 (Ad Theodorum), PG 37, 217, POK 15, 165.

${ }^{32}$ Epistula 129 (Ad Procopium), PG 37, 224, POK 15, 170-171.

${ }^{33}$ Epistula 130 (Ad Procopium), PG 37, 225, POK 15, 172.

${ }^{34}$ Tamże.
} 
$\mathrm{Z}$ tych słów tchnie niechęć Grzegorza do tego typu zbiorowych zjazdów zwierzchników kościelnych, z powodu doznanych wcześniej utrapień $\mathrm{z}$ ich strony. O niemożliwości przyjazdu na synod Grzegorz napisał także Olimpiuszowi, namiestnikowi Kapadocji, skarżąc się na zły stan zdrowia:

„To jest dla mnie od samej choroby cięższe, że się nie wierzy choremu, lecz nakazuje mi tak długą podróż, [...], mam w tobie wiarygodnego świadka mojej choroby"35.

Te słowa, napisane do urzędnika państwowego, mają zatem uwiarygodnić uczestnikom synodu jego nieobecność na nim.

Nazjanzeńczyk nie podaje jednak rodzajów choroby, na które zapadał, ani też nie wymienia imion lekarzy, którzy dbali o jego zdrowie, natomiast w swych listach oświadcza swoim adresatom o pobycie w zdrojowej miejscowości - Ksanksarydzie. Olimpiusz otrzymał list, w którym dowiaduje się o tym fakcie w następujących słowach:

„Skoro jednak niemoc zapędziła mnie zbyt daleko, bo trzeba było za radą lekarzy korzystać z cieplic Ksanksarydy - wyręczam się listem"36.

Ten tekst jest dowodem na to, że zdrowie było dla Kapadocczyka cenne, skoro był gotów pojechać w odpowiednie miejsce dla podratowania kondycji cielesnej. Kolejny list, słany do Olimpiusza, zawiera informację o przypadkowym jego przyjeździe w okolice przebywania Grzegorza, który bardzo pragnie spotkać się z namiestnikiem. $Z$ tego też powodu biskup Kapadocji przyspiesza swą kurację, aby to osiagnąć, co po pewnym czasie tak relacjonuje:

„Zaniesiono mnie do klasztoru, bym doznał jakiejś ulgi przez kapiele: potem spodziewałem się spotkania z tobą i już niby w dłoni miałem to szczęście [...] - gdy z nagła odepchnęła mnie choroba, z obecnymi i grożącymi udrękami”"37.

Treść tego listu jest jednak dowodem na to, że choroba Kapadocczyka musiała być niezwykle poważna, skoro pobyt w miejscowości zdrojowej nie przyniósł szybkiego powrotu do zdrowia.

Teodor, towarzysz Grzegorza z czasów jego działalności w Konstantynopolu, wśród wielu informacji zawartych w otrzymanym liście mógł także przeczytać o decyzji podjęcia na nowo obowiązków pasterskich w Nazjanzie:

„Nie usunąłem się od Kościoła w Nazjanzie ani jakobym Bogiem pogardzał albo z góry patrzał na małą owczarnię, [...] złamany jestem chorobą i nie czuję się na siłach do takich trosk. [...] Oddaję to podłe ciało Kościołowi, póki sił; sądzę, że lepiej jest raczej coś wycierpieć na ciele, niż zgorszyć się na duszy"38.

\footnotetext{
${ }^{35}$ Epistula 131 (Ad Olympium), PG 37, 225, POK 15, 173.

${ }^{36}$ Epistula 125 (Ad Olympium), PG 37, 220, POK 15, 166.

${ }^{37}$ Epistula 126 (Ad Olympium), PG 37, 221, POK 15, 168.

${ }^{38}$ Epistula 139 (Ad Theodorum), PG 37, 236, POK 15, 181.
} 
Ta wypowiedź świadczy o wielkim zaangażowaniu Grzegorza w bieżące sprawy Kościoła. Jest tym samym wielkodusznym świadectwem jego pasterskiego powołania, gdyż mimo choroby i braku sił dobrowolnie oddaje się na służbę dla lokalnej wspólnoty. Po przyjęciu tej posługi wnet jednak dochodzi do jego interwencji u Olimpiusza, ponieważ ten zagroził mieszkańcom Nazjanzu, którzy wywołali zamieszki z powodu zmian w samorządzie miejskim. Wówczas Grzegorz odważył się napisać:

„Znowu pora na miłosierdzie - znowum na tyle zuchwały, by pismu powierzyć błagalną prośbę w tak ważnej sprawie. Ośmiela mnie choroba moja, która nie pozwala mi nawet wyjść"

Choroba, na którą ciągle jeszcze cierpi biskup, ma w tym wydarzeniu charakter instrumentalny i wspomagający w załatwieniu u namiestnika istotnej sprawy dla obywateli Nazjanzu. Ten sam monit Grzegorz umieścił w następnym liście, gdzie ponownie pisze, iż ,proszący [jest] w ogromnych opałach - ale choroba jest nieugięta"40.

Punktem zwrotnym w misji pełnionej w Nazjanzie była, niestety, znowu choroba. O jej destruktywnym działaniu zwierza się Teodorowi, metropolicie Kapadocji Drugiej, do której Nazjanz należał. W liście pisanym do niego kilkakrotnie informuje go o stanie zdrowia, prosząc o zwolnienie z pełnionej funkcji. Pełen goryczy z powodu nie najlepszej kondycji tamtejszej wspólnoty zwraca się do swego zwierzchnika:

„Na kogo przejdzie ciężar Kościoła, który tak źle się ma, tak jest rozprzężony? Świadczę wobec Boga i wybranych aniołów, że owczarnia Pańska niesprawiedliwość cierpi, wskutek mego zamierania jest bez pasterza, bez nadzoru. Mnie bowiem choroba dzierży, zbyt szybko oderwała mnie od spraw Kościoła" ${ }^{\prime 1}$.

W tych słowach Grzegorz kieruje się troską o Kościół. Jest gotów dalej służyć owczarni Chrystusa, jednak coraz bardziej jest świadomy tego, że brakuje mu sił. Swą bezsilność wyznaje w dalszym ciągu listu, skarżąc się na obecność apolinarystów zagrażających stabilności lokalnego Kościoła. W związku z tym kieruje do Teodora prośbę, która jest wręcz zaleceniem:

„Zatroszcz się o swój Kościół, jakim chcesz sposobem, i nie patrz obojętnie na jego niezasłużenie smutny stan. [...] Powstrzymać te napaści - to nie na mój wiek i chorobę, lecz na twoją przytomność umysłu i twoje siły. [...] Kościół potrzebuje biskupa, by nie ucierpieć z powodu mojej choroby" ${ }^{\prime 2}$.

Również ta wypowiedź jest wołaniem schorowanego Grzegorza o podjęcie odpowiedzialnych decyzji odnośnie do losu kościelnej wspólnoty w Nazjanzie.

\footnotetext{
${ }^{39}$ Epistula 141 (Ad Olympium), PG 37, 240, POK 15, 183.

${ }^{40}$ Epistula 142 (Ad Olympium), PG 37, 244, POK 15, 186.

${ }^{41}$ Epistula 152 (Ad Theodorum), PG 37, 257, POK 15, 196.

${ }^{42}$ Tamże, POK 15, 196-197.
} 
Ta chorobą powodowana rezygnacja z pełnionych obowiązków z pewnością przysparzała biskupowi dodatkowych cierpień duchowych. Po pewnym czasie jednak stan zdrowia Grzegorza poprawił się, skoro w liście do Amfilochiusza, biskupa Ikonium, wyznał:

„Ledwiem wytchnął po udrękach choroby, spieszę do ciebie, przyczyno mego wyleczenia. Bo język kapłana, wyznający Panu, dźwiga chorujących"43.

Obok informacji o poprawie zdrowia Grzegorz dał także piękne świadectwo o mocy modlitwy wstawienniczej współbrata w kapłaństwie.

Gdy Kapadocczyk został odciążony od dobrowolnego obowiązku pełnienia posługi pasterskiej w Nazjanzie, którą zdecydował się zakończyć z powodu przeciagającej się choroby, przeniósł się z powrotem do prywatnych posiadłości. W listach, które stamtąd adresował, dalej skarżył się na ataki choroby, ujmując ją jednak częstokroć w kontekście ironii w odniesieniu do własnej osoby. Pierwsze zdanie listu do Eudoksjusza jest na to dowodem:

„Żalisz się, że nie piszę, a sam nie należysz - myślę - do piszących dużo, chyba że wskutek choroby od rzeczy plotę i pamięć straciłem doznanych dobrodziejstw"44.

Podobny ton można zaobserwować w listach do Prokopiusza, prefekta Konstantynopola. W pierwszym z nich Grzegorz usprawiedliwia swą nieobecność na weselu Olimpiady:

„Tylko nie sposób było, mniemam, czując się tak tragicznie, wystapić radośnie, a przy tym wcale niewczesny to i nieweselny widok: dwa kulasy obnoszone i wyśmiewane wśród pląsających!" 45 .

Ten weselny żart zdradza przy okazji, że Grzegorz cierpiał na chorobę nóg, prawdopodobnie podagrę. Również w drugim liście adresat mógł zauważyć ironiczny nastrój Kapadocczyka względem siebie:

„Słodki ciężar zrzucasz, dobrze robisz, A jam gnuśny, jak może sam powiesz.

Żeby prawdę powiedzieć, chory, a nie gnuśny"46.

Grzegorz, nowy namiestnik Kapadocji, mógł się także przekonać o dowcipnym języku Nazjanzeńczyka:

„Gdybym na tyle był zdrowy, żeby ciało mogło służyć porywom duszy - niktby wcześniej ode mnie nie przybiegł i nie uścisnął ciebie, niktby wcześniej nie złożył życzeń przy objęciu urzędu. Niestety, słońce chmura zamracza, mnie zaś choroba i to zazdrosne cielsko, to więzienie" ${ }^{\prime 47}$.

\footnotetext{
${ }^{43}$ Epistula 171 (Ad Amphilochium), PG 37, 280, POK 15, 211.

${ }^{44}$ Epistula 187 (Ad Eudoxium), PG 37, 305-308, POK 15, 231.

${ }^{45}$ Epistula 193 (Ad Procopium), PG 37, 316, POK 15, 238.

${ }^{46}$ Epistula 194 (Ad Procopium), PG 37, 317, POK 15, 239.

${ }^{47}$ Epistula 195 (Ad Gregorium praesidem), PG 37, 320, POK 15, 240.
} 
Ten cytat pokazuje, jak w bieżące sprawy życia społecznego Grzegorz podpiął myśl o stanie zdrowia, przekonując adresata, że ono wszystkiemu winne. Tę samą argumentację zastosował w liście do prefekta Kapadocji, Nemezjusza:

„Tęsknię zobaczyć się z tobą, ale przeszkadza mi choroba i nie mogę dosięgnąc tego szczęścia" ${ }^{\text {"48 }}$.

A kiedy Nemezjusz ustępował z urzędu, Grzegorz wysłał pożegnalny list, pisząc o pragnieniu spotkania się z nim, przy czym dodał że „nie tak łatwo, gdy zdrowie jest w takim stanie, w jakim jest" 49 .

Obecność ironii i żartu - jak to widoczne jest w powyższych cytatach z korespondencji Grzegorza - świadczą raczej o spokojnym przebiegu choroby. Gdy natomiast jej ataki przynosiły więcej bólu, znika w innych jego listach ironia, a pojawia się chłodna relacja o stanie zdrowia, którego brak jest powodem rozmaitych wyjaśnień. Do Grzegorza z Nyssy pisze:

„Powstrzymał mnie zjazd, który obchodzicie tam na cześć świętych męczenników, bo i niezdolny byłem uczestniczyć w nim z powodu choroby"50.

Do Adelfiusza, młodzieńca z szlacheckiego rodu, w ten sam sposób tłumaczy niemożliwość przybycia do miejscowości jego zamieszkania:

„Dlatego nie odmów wiary memu usprawiedliwieniu, że zajęcia i choroba tchawicy przeszkodziły mi przybyć do Nauiloi”51.

Tym razem Kapadocczyk wymienił rodzaj choroby, jaka była powodem pozostania w domu, a mianowicie choroba płuc. Dalsza treść listu nie podaje, czy było to czasowe niedomaganie czy też chroniczne cierpienie, będące częstym przedmiotem jego korespondencyjnych relacji. Zatem obok choroby nóg, prawdopodobnie podagry, o czym była mowa wyżej, Grzegorz cierpiał również na chorobę płuc.

Listy z ostatnich lat życia Grzegorza często zawierają stwierdzenia dotyczące zamiaru odwiedzin swoich znajomych. List do Jakuba, namiestnika Kapadocji, w którym poleca mu Symplicję, wdowę po Alipiuszu, a właściwie jej prawne sprawy, rozpoczyna się następująco:

„Gdybym był na tyle zdrów, by sprostać trudom, sambym do was przybył: nasyciłbym tęsknotę zobaczenia się z wami i pogadałbym o tym, co mi na sercu leży"s2.

Wprawdzie list ma charakter wstawienniczy, jego autor odsłania także swoje duchowe oblicze: pisze o tęsknocie zobaczenia się i pragnieniu otwarcia

\footnotetext{
${ }^{48}$ Epistula 199 (Ad Nemesium), PG 37, 325, POK 15, 245.

${ }^{49}$ Epistula 200 (Ad Nemesium), PG 37, 328, POK 15, 246.

${ }^{50}$ Epistula 197 (Ad Gregorium Nyssenum), PG 37, 321, POK 15, 242.

${ }^{51}$ Epistula 205 (Ad Adelphium), PG 37, 340, POK 15, 253.

${ }^{52}$ Epistula 207 (Ad Jacobum), PG 37, 344, POK 15, 256.
} 
swego serca. W podobny sposób Kapadocczyk rozpoczął list do mnicha Homofroniusza:

„Wzywasz mnie na zebranie. Chciałbym ci ja tak się czuć zdrowym, by móc i z własnej pobudki bawić wśród was, zobaczyć wasz święty dom, schronisko Chrystusowe, korzeń świętych rozgałęzień" ${ }^{33}$.

Inicjatywa spotkania wychodzi od autora listu, który zdaje sobie sprawę $\mathrm{z}$ tego, że nie zobaczy tego, co piękne u adresata, tj. świętego domu, będącego wręcz „schroniskiem Chrystusowym” - jak napisał. Również Tekla, siostra prezbitera Sacerdosa, także w pierwszym zdaniu otrzymanego listu przeczytała o zamiarze przybycia Grzegorza, który tak się do niej zwrócił:

„Wybierałem się i osobiście do twej pobożności, chociaż ciało moje słabowało, zarazem by cię odwiedzić i pochwalić za siłę ducha, na którą zdobywasz się wobec śmierci błogosławionego brata twego" ${ }^{54}$.

Przyczyną przyjazdu miało zatem być okazanie współczucia z powodu śmierci brata Tekli. Ta wypowiedź odsłania ponadto duchową więź, jaka łączyła Grzegorza z Sacerdosem i Teklą. I w tym przypadku choroba stała się przeszkodą w realizacji jego międzyludzkich zobowiązań. Spotkanie z serdecznym przyjacielem Euzebiuszem również nie doszło do skutku: „Kilka razy wybierałem się, kilka razy zawahałem się - w końcu uległem chorobie"

W ostatnich listach pisanych przez Grzegorza, obok wzmianek o chorobie, można spotkać również myśli nawiązujące do relacji przyjacielskich, ponieważ wśród adresatów było wielu oddanych mu przyjaciół. Z pewnością należał do nich Kastor, urzędnik z Konstantynopola, do którego pisał:

„[...] obczyzna jest łaskawsza. Ta bowiem dała mi korzystać z twojej przyjaźni [...]. A płata mi to choroba, która trzyma mnie w pętach i czyni do wszystkiego nieruchawym czy raczej - mówiąc ściśle - nieruchomym"

Jest to fragment listu wstawienniczego, z którego czytelnik dowiaduje się o przyjaźni z Kastorem oraz o przewlekłej chorobie. O niej dowiedział się także dostojnik wojskowy Ellebichus, który w otrzymanym liście przeczytał:

„Jaką stratę ponoszę z powodu choroby! Należałoby pobiec do ciebie, uścisnąć, przypomnieć ci dawną przyjaźń i zażyłość. Niestety, nie tak dobrze jest $\mathrm{z}$ ciałem moim"s7.

Grzegorz odwołuje się znowu do przyjaźni, łączącej go z adresatem, nadmieniając o chorobie, która stoi na przeszkodzie spotkania się w Konstantynopolu.

\footnotetext{
${ }^{53}$ Epistula 221 (Ad Homophronium), PG 37, 361, POK 15, 268.

${ }^{54}$ Epistula 222 (Ad Theclam), PG 37, 361, POK 15, 269.

${ }^{55}$ Epistula 231 (Ad Eusebium), PG 37, 373, POK 15, 277.

${ }^{56}$ Epistula 210 (Ad Castorem), PG 37, 348, POK 15, 258.

${ }^{57}$ Epistula 225 (Ad Ellebichum), PG 37, 369, POK 15, 273.
} 
$\mathrm{Z}$ powodu stanu zdrowia było bowiem rzeczą niemożliwą wybrać się $\mathrm{w}$ tak daleką podróż. Bywało też jednak, że Nazjanzeńczyk czuł się lepiej, o czym donosił Ursusowi, pisząc:

„Miło pozdrawiać przyjaciół - a przez przyjaciół tym milej. Jednym z nich to najdroższy syn mój Anyzjusz, który przyniesie wam radosną nowinę o mym zdrowiu - jeśli można zdrowiem nazwać nieznaczny wzrost ku lepszemu"s58.

Można się wczuć w stan ducha Grzegorza i podzielać radość, jaką przeżywa, gdy w czasie chronicznego stanu chorobowego pojawiła się poprawa zdrowia, co nazwał ,radosną nowiną".

3. Szukanie ukojenia. Bardzo często spotykanym w korespondencji Grzegorza z Nazjanzu stanem ducha jest dążność do duchowego wyciszenia. Niezwykle znamienne są słowa, skierowane do Nektariusza, arcybiskupa Konstantynopola, po powrocie w rodzinne strony, gdy na własną prośbę zrezygnował ze służby pasterskiej w stolicy. Początek listu jest następujący:

„Co do mnie, to powodzi mi się jako tako: siedzę z dala od wojny i kłopotów, chwaląc nade wszystko bezpieczną nagrodę milczenia" ${ }^{\circ 9}$.

Treść tej wypowiedzi zdradza radość Kapadocczyka, jaka pojawiła się w jego życiu po oderwaniu się od niemiłej atmosfery ostatnich miesięcy pobytu w Konstantynopolu. To, co tam miało miejsce, Grzegorz nazwał „wojną i kłopotami”, tymczasem sytuacja przez niego opisywana jest dla niego „nagroda milczenia". W tym wyrażeniu obecne są dwie korzyści: owoc jego decyzji o rezygnacji stanowi dla niego nagrodę, a milczenie, którym się szczyci, jest dla niego przeciwstawnym uczuciem wobec wspomnianych kłopotów.

Nie tylko najważniejszy dostojnik kościelny w stolicy dowiedział się o kondycji duchowej Grzegorza po rezygnacji, ale także inni jego bliscy z tego miasta. Sofroniusz, prefekt Konstantynopola, miał sposobność osobistego przekonania się o tym z listu, który otrzymał:

„Ma coś dodatniego moje usunięcie się: beztroskę, spokój, ale nie tyle, co ujemnego, bo odcina mnie od waszej przyjaźni i współżycia z wami”" ${ }^{\prime}$.

Również w tej wypowiedzi zawierają się dwa przeciwstawne odczucia: z jednej strony beztroska i spokój, które nastąpiły po okresie pasterskiej troski i kościelnej wrzawy podczas synodu, a z drugiej - odizolowanie od przyjacielskich relacji, będących ważną częścią jego codziennego życia. O innej sytuacji życiowej Grzegorza po rezygnacji został poinformowany kolejny jego przyjaciel, Amazoniusz:

\footnotetext{
${ }^{58}$ Epistula 227 (Ad Ursum), PG 37, 369, POK 15, 274.

${ }^{59}$ Epistula 91 (Ad Nectarium), PG 37, 165, POK 15, 122.

${ }^{60}$ Epistula 93 (Ad Sophronium), PG 37, 168, POK 15, 123.
} 
„Jeśliby któryś z naszych wspólnych przyjació - a tych jest, myślę, dużo ciebie zapytał: Gdzie jest teraz Grzegorz? co porabia? - opowiedz śmiało, że filozofuje w spokoju" ${ }^{61}$.

Ten fragment listu przywołuje znowu relacje przyjaźni, które Grzegorz w Konstantynopolu pielęgnował, a przede wszystkim podkreśla spokój, jakiego doznaje w Kapadocji. Natomiast w liście do prezbitera Leontiusza chwali nawet swą chorobę, którą odbiera jako powód nastania nowego okresu w swoim życiu: Oto słowa kapadockiego pasterza:

„O błogosławiona choroba, błogosławiona napaść wrogów, przez którą uwolniłem się od ognia sodomskiego i rozprzężenia wśród biskupów!"62

Również ta wypowiedź nawiązuje do przykrych wydarzeń, jakie Grzegorz przeżył podczas krótkiego pobytu w stolicy. Dla uwolnienia się od nich z pomocą przyszła mu choroba, którą w tym liście akurat chwali.

Natomiast Kledoniusz, prezbiter z Ikonium, zarządzający Kościołem w Nazjanzie, stał się adresatem kilku bardzo krótkich listów, w których za każdym razem Grzegorz porusza fakt swego milczenia:

„Pytasz, do czego zmierza moje milczenie. Szuka miary mówienia i cichości.

[...] Ponadto i serce uśmierza - nierozgadane, w sobie skupione"63.

W Konstantynopolu Grzegorz z powodu duszpasterskiego zaangażowania był zmuszony do częstego przemawiania, prowadzenia dyskusji czy też organizowania życia kościelnego, używając do tego swej mowy. Tymczasem w Kapadocji, całkowicie oderwany od tych obowiązków, pozostawało mu jedynie milczenie. Grzegorz zauważył więc tę zasadniczą różnicę i na co dzień doświadczał tej nowej rzeczywistości. Zauważa bowiem, że milczenie przynosi miarę w mówieniu i cichość, a także skupienie w głębi serca. Swego rodzaju kontynuację stanowi kolejny list: „Milczę, by się nauczyć mówić, co trzeba; ćwiczę się w thumieniu wzburzeń" ${ }^{64}$. Kapadocczyk odkrywa inne walory owego „przymusowego” milczenia i tym dzieli się z Kledoniuszem. „Choć język milczy, na twe słowa chętnie uszu nadstawię" ${ }^{65}$ - to słowa następnego listu do Kledoniusza. Grzegorz przekonuje adresata, że mimo milczenia, należy też umieć słuchać.

Milczenie, które dla Grzegorza jako wytrawnego retora i mówcy było obce w okresie młodości i w wieku dojrzałym, musiało stać się potem niebywałym doświadczeniem, o którym dowiaduje się także Palladiusz:

\footnotetext{
${ }^{61}$ Epistula 94 (Ad Amasonium), PG 37, 168, POK 15, 124.

${ }^{62}$ Epistula 95 (Ad Leontium), PG 37, 168-169, POK 15, 125.

${ }^{63}$ Epistula 107 (Ad Cledonium), PG 37, 208, POK 15, 156.

${ }^{64}$ Epistula 108 (Ad Cledonium), PG 37, 208, POK 15, 156.

${ }^{65}$ Epistula 109 (Ad Cledonium), PG 37, 208, POK 15, 156.
} 
„Nowy to sposób pracy nad sobą! Skorom w czasie mówienia nie poskramiał języka, ust zamknięciem nauczyłem się milczeć, urabiając podobne przez podobne"66.

Z tych słów jasno wynika, że Grzegorz odkrywa kolejne pokłady chrześcijańskiej duchowości. Całkiem inaczej przeżywany okres życia, w którym dominuje przede wszystkim milczenie, wprowadzające go też na inne tory duchowego doskonalenia, co w liście opisuje jako „nowy sposób pracy nad sobą”. W następnym liście pisanym do Palladiusza Grzegorz relacjonuje o innym aspekcie praktyki milczenia:

„Dla Chrystusa umartwiałem język [...]. Tym dla mnie misterium milczenia: ofiarowałem Mu serce nierozgadane, by mu tak samo ofiarować mowę oczyszczoną"67.

Należy zauważyć, że podjęte przez Nazjanzeńczyka milczenie, traktowane jest przez niego jako misterium skierowane ku Chrystusowi. Umiejętność retorycznego przemawiania została przez to misterium oczyszczona i ofiarowana Temu, w którego Imię przemawiał. Bez wątpienia, to osobiste świadectwo Grzegorza jest wejściem na jeszcze wyższy poziom duchowego rozwoju.

Swym duchowym doświadczeniem Grzegorz podzielił się także z Eulaliuszem, późniejszym biskupem Nazjanzu. Napisał do niego krótki list, który warto tu w całości przytoczyć:

„Ty uprawiasz samotność i tak nieumiarkowane posty, ja milczenie. Udzielmy sobie nawzajem duchowych korzyści. Gdy się zejdziemy, wspólnie śpiewać będziemy Bogu, owocując i w wymowne milczenie i w mowę natchnioną"

$\mathrm{Z}$ tego tekstu tchnie nie tylko sztuka retoryki, ale także coraz głębsza dojrzałość duchowa, polegająca na chęci dzielenia się z innymi ludźmi swymi osiagnnięciami, czyli - jak to nazwał Kapadocczyk - „duchowymi korzyściami”. Mają one wymowę eschatologiczną, ponieważ staną się kiedyś istotnymi darami przed Bogiem. Grzegorz napisał do Eulaliusza jeszcze trzy listy. Z pierwszego czytelnik dowiaduje się, że jego autor nałożył sobie milczenie, w którym trwał nieugięcie mimo odwiedzin mnichów w Lamidzie:

„Była dla mnie Lamida i miejscem milczenia i ćwicznią filozofii. Jakem ją widział w czasie milczenia, tak pragnę ją zobaczyć teraz, kiedy mówię"

Można by wnioskować, że w pierwszym etapie pobytu Grzegorza w prywatnych posiadłościach milczenie pojawiło się jako efekt braku kontaktów i obowiązków pasterskich, natomiast po jakimś czasie nastapiło odkrycie dobroczynnego działania milczenia. $Z$ tego też względu mogło ono następnie stać się narzuconą przez siebie praktyką ascetyczna, tak radykalnie realizowaną, że nawet

\footnotetext{
${ }^{66}$ Epistula 110 (Ad Palladium), PG 37, 208, POK 15, 156.

${ }^{67}$ Epistula 119 (Ad Palladium), PG 37, 213, POK 15, 161.

${ }^{68}$ Epistula 111 (Ad Eulalium), PG 37, 209, POK 15, 157.

${ }^{69}$ Epistula 116 (Ad Eulalium), PG 37, 212-213, POK 15, 160.
} 
odwiedziny w klasztorze nie złamały jego postanowienia. W kolejnym liście Grzegorz ujawnia, podobnie jak Palladiuszowi, swoje odniesienia do Chrystusa:

„Zdarzyło mi się coś dziwnego: przy tobie milczałem, za nieobecnym tęsknię, chcąc się słowem podzielić i słowo odebrać"70.

$\mathrm{Z}$ tego sformułowania wynika, że milczenie pociagga za sobą tęsknotę za Bogiem, która powoduje pragnienie, by z Nim zacząć rozmawiać. Jest to inny znowu aspekt zbawiennej izolacji Grzegorza od świata, także tego kościelnego. Wreszcie Eulaliusz poznał jeszcze inne, bardziej zaskakujące stwierdzenie Kapadocczyka:

„«Milczałem» bowiem, mówi Pismo, ale czy zawsze milczeć mam?

Milczałem dla siebie, a mówię dla drugich"71.

To rozróżnienie pomiędzy sobą a drugimi jest również bardzo istotne w relacjach międzyludzkich.

Ta jednak duchowa wartość, którą Nazjanzeńczyk posiadł dzięki oderwaniu się od zgiełku światowego, rozumiana przez kilka bliskich mu osób z grona kościelnego, nie była zaakceptowana w ogóle przez Keleuzjusza, urzędnika miejskiego w Nazjanzie, do którego Grzegorz napisał:

„Przyjąłem cię w milczeniu, byś poznał także mowę milczenia, piórem się wypowiadająca" ${ }^{2}$.

Biskup chciał widocznie podzielić się duchową umiejętnością, aby także jego rozmówca doznał głębszych wzruszeń. Urzędnik jednak nie przekonał się do tej metody porozumiewania się zaprezentowanej przez Grzegorza, który w kolejnym liście posłanym do niego pisał:

„Nie sądź mnie, że milczę, bo ja ciebie nie sądzę, że gadasz. Jeśli zaś mnie sądzisz, to bój się mego języka"73.

Ta wypowiedź podkreśla pełną świadomość Kapadocczyka co do swoich umiejętności - zarówno sztuki przemawiania, jak i milczenia. Adresat listu mógł nie znać ciętego języka Grzegorza, o czym przekonał się z następnego listu:

„Skoro mi zarzucasz milczenie i nieogładę, [...] może mi się uda oduczyć cię bredzenia. [...], a jeśli moje zaniemówienie uznasz za lepsze od swojego rozjęzyczenia - przestań bluźnić mojemu milczeniu"74.

Praktyka milczenia stała się dla Grzegorza jedną z postaw jego życia prowadzonego w samotności, z czego był bardzo zadowolony. Czasami unikał spotkań, zwłaszcza zebrań biskupów. Na takie właśnie zapraszał go sam

\footnotetext{
${ }^{70}$ Epistula 117 (Ad Eulalium), PG 37, 213, POK 15, 161.

${ }^{71}$ Epistula 118 (Ad Eulalium), PG 37, 213, POK 15, 161.

${ }^{72}$ Epistula 112 (Ad Celeusium), PG 37, 209, POK 15, 157.

${ }^{73}$ Epistula 113 (Ad Celeusium), PG 37, 209, POK 15, 158.

${ }^{74}$ Epistula 114 (Ad Celeusium), PG 37, 209-212, POK 15, 158-159.
} 
cesarz Teodozjusz, który poprzez Prokopiusza przekazywał jego wolę. W odpowiedzi Grzegorz napisał:

„Dlatego cofnąłem się w swe wnętrze i za jedyną ostoję duszy uznałem - spokój”"75.

Słowa te świadczą o docenieniu duchowej sfery człowieka, która może stać się nawet „ostoją”, jak jąuznał biskup kapadocki. Wnętrze człowieka i spokój przeważyły w decyzji wyjazdu na synod. Również Olimpiusz, namiestnik Kapadocji, zapraszał Grzegorza na ten sam synod. Odpowiedź jego była jednoznaczna: „Bezkłopotliwy spokój jest wszak cenniejszy od blasku wśród kłopotów"76. W podobnym duchu Grzegorz pisał do Tymoteusza, bliżej nieznanego chrześcijanina:

„Ustapiłem przed zawiścią, filozofuję w spokoju dla Boga, skupiam się modlitewnie w sobie - ze zgiełku i wrzawy się wyrwałem""77.

W tych słowach biskup streścił swoje codzienne zajęcia, w których przeważa rozmyślanie o Bogu i skupienie modlitewne ${ }^{78}$.

4. Bliskość śmierci. Wyżej wspomniane rozmyślanie o Bogu należy w refleksjach Grzegorza traktować jako chęć spotkania się z Nim, najpierw w kontemplacji, a potem „twarzą w twarz”. Jego myśli o śmierci były następstwem przykrych doświadczeń w Konstantynopolu, o czym jawnie pisze w swoich listach. Filagriusz, przyjaciel Grzegorza, nie mógł zrozumieć jego lekkomyślnej decyzji pozostawienia pasterskiego obowiązku. List, który otrzymał, wyjaśnia motywy opuszczenia stolicy i szczerze w nim wyznaje:

„Dlatego postanowiłem, jak to mówią, «okręt wycofać» [...] i z dala patrzyć, jak inni nawzajem się biją, sam zaś przenieść się ku sprawom zaświatowym"’79.

Autor listu jasno określił, jak widać, stan, w którym się znalazł, i oznajmił przyjacielowi o pragnieniu rychłego przejścia w świat pozamaterialny. List o podobnej treści otrzymał od niego również Focjusz, sofista z Konstantynopola, w którym Grzegorz wyjaśnia swą decyzję:

„Może nie małą cząstkę dołożyłem do obecnego stanu Kościoła, póki byłem jeszcze w wirze spraw i przewodniczyłem chwili. Teraz zaś jedno tylko mnie obchodzi: odlot stąd, do którego się zbieram i gotuję"

Należy zauważyć, że decyzja o rezygnacji z urzędu biskupiego w stolicy nie jest równoznaczna $\mathrm{z}$ rezygnacją z życia, czyli natychmiastowym odejściem

${ }^{75}$ Epistula 130 (Ad Procopium), PG 37, 225, POK 15, 172.

${ }^{76}$ Epistula 131 (Ad Olympium), PG 37, 225, POK 15, 173.

${ }^{77}$ Epistula 164 (Ad Timotheum), PG 37, 273, POK 15, 206.

${ }^{78}$ Elementy duchowości Grzegorza z Nazjanzu przedstawił m.in. Th. Špídlík, La teoria et la praxis chez Grégoire de Nazianze, StPatr 14 (1976) 358-364.

${ }^{79}$ Epistula 87 (Ad Philagrium), PG 37, 161, POK 15, 119.

${ }^{80}$ Epistula 168 (Ad Photium), PG 37, 277, POK 15, 210. 
z tego świata. Grzegorz do „odlotu”, jak się wyraził, zamierza się przygotować i duchowo nastawić.

Kapadocczyk w sposób identyczny objaśniał swoją decyzję także biskupom. Wiadomo było, że jego aktywność nie wszystkim się podobała, co też po pewnym czasie uświadomił sobie i w liście do Helladiusza, biskupa Kapadocji Drugiej, oznajmia, nawiązując do wydarzeń biblijnych przy opisie swej osoby:

„Jam już wiele Pasch przebył: tyle zysku miałem z długiego żywota. Teraz do czystej Paschy tęsknię, by wyszedłszy z Egiptu tego ciężkiego i mrocznego życia i uwolniony od tego błota i cegieł lepienia, do którego przykuci jesteśmy, dostać się do Ziemi Obiecanej”»1.

Ten tekst dobrze oddaje przeżycia, jakich doznawał Grzegorz podczas pasterskiej posługi. Porównał je do ciężkiego i mrocznego życia w Egipcie. Tymczasem teraz jego marzeniami są: czysta Pascha i Ziemia Obiecana. Po niedługim czasie Helladiusz otrzymał od niego list z podziękowaniami za przesłane Grzegorzowi upominki świąteczne, którego zakończenie brzmi następująco:

,[...] bym przeniesiony został tam i prawdziwe święto pojął czy ujrzał, gdzie mieszkanie wszystkich rozradowanych: bo gmatwaniny żywota syt już jestem"s2.

Ta wypowiedź ujawnia jeszcze bardziej intensywniejszą chęć ucieczki Grzegorza z tego pogmatwanego żywota w krainę rozradowanych mieszkańców. Poprzez tę metaforę oznajmia, że czeka na śmierć, by móc prawdziwie świętować. Swą duchową sytuację przedstawił także Bosporiuszowi, biskupowi Kolonii: „Ucieknę do Boga: On jeden czysty, On jeden bez podstępu! Cofnę się w siebie"83. To wyznanie Grzegorza, obok pragnienia kontemplowania Boga, zawiera także gorzką prawdę o latach minionych, w których przeżywał to, co jest zaprzeczeniem Boga, a więc sytuacje o intencjach nieczystych i pełnych podstępu.

Bardzo osobiste listy w swej treści otrzymał również bliski przyjaciel Nazjanzeńczyka - Grzegorz z Nyssy. W jednym z nich, przedstawiając rzeczywisty przebieg obsadzenia stolicy biskupiej w Nazjanzie, proponuje na biskupa Eulaliusza, o którym tak napisał:

„Jego to do rąk ci polecam, czcigodnego Eulaliusza, Bogu miłego biskupa, na którego ramionach pragnąłbym ducha oddać" ${ }^{84}$.

Autor tych słów myślał o końcu swego życia nawet w trakcie załatwiania spraw bieżącego życia kościelnego. Przy okazji wydał o Eulaliuszu piękne świadectwo. W innym znów liście, którego treść jest pocieszeniem po śmierci siostry Teozebii, Grzegorz ujawnił swoje duchowe nastawienie:

\footnotetext{
${ }^{81}$ Epistula 120 (Ad Helladium), PG 37, 216, POK 15, 162.

${ }^{82}$ Epistula 172 (Ad Helladium), PG 37, 281, POK 15, 213.

${ }^{83}$ Epistula 153 (Ad Bosporium), PG 37, 260, POK 15, 197-198.

${ }^{84}$ Epistula 182 (Ad Gregorium Nyssenum), PG 37, 297, POK 15, 224.
} 
„Pragnę zaś i ja - wiedz dobrze - rozstać się ze światem, chociaż nie tak gorąco, jak wy - to za śmiałe słowo - ale zaraz po was" ${ }^{" 85}$.

Również ta wypowiedź zawiera oświadczenie Grzegorza o jego pragnieniu odejścia $\mathrm{z}$ tego świata ${ }^{86}$. Jak zaznacza, ma to się stać według swoistej kolejności. Takie podejście do tego kulminacyjnego momentu życia wypływa o czym już wyżej powiedziano - z chęci właściwego przygotowania się poprzez kontemplację i modlitwę.

5. Prośba o modlitwę. Okres, jaki Grzegorz z Nazjanzju spędził w rodzinnych stronach, był nie tylko czasem kontemplacji, jak to wyżej zaznaczono, ale także wielokrotnymi, jak to widać w jego korespondencji, ponawianymi prośbami o modlitwę za siebie. Był to także okres częstego popadania w różne choroby i nieustannych jej nawrotów. Szczególnie uciążliwie Grzegorz przeżywał pierwszy atak choroby po opuszczeniu stolicy biskupiej w Konstantynopolu. Ciesząc się dotąd względnie dobrym zdrowiem, w rodzinnych stronach zaczął doświadczać, czym jest ból i cierpienie. W takim zapewne kontekście życiowym prosi Prokopiusza o modlitwę, poprzedzając tę prośbę skargą na dokuczliwą chorobę:

„Módl się, by mi Bóstwo było łaskawe. Jedno z dwojga wtedy nastapi: albo ujdę całkowicie tych katuszy, albo wytrwam cierpliwie" $"$.

Jest to prośba o modlitwę wstawienniczą: Grzegorz pragnie być zdrowy i jest o tym głęboko przekonany.

Prośbę o zdrowie Grzegorz kilka razy kierował także do Teodora, swego towarzysza, potem prawdopodobnie biskupa, w chwili, gdy nie mógł go odwiedzić:

„Zaklinam, bądź trochę cierpliwy, proś o moje zdrowie: jak tylko pora będzie, stawię się na twe prośby" ${ }^{\prime 8}$.

Również w innym liście do niego błaga o to samo:

„W szczerej tęsknocie pomóż modlitwą, bym osiągnął, do czego zdążam"\$9.

Bezpośrednim celem Kapadocczyka było spotkanie z adresatem, by zaspokoić tęsknotę za zobaczeniem go. Było to jednak niemożliwe z powodu braku zdrowia, o które prosi w modlitwie. Niedługo potem Teodor ponownie odczytuje tę samą prośbę:

${ }^{85}$ Epistula 197 (Ad Gregorium Nyssenum), PG 37, 321, POK 15, 242.

${ }^{86}$ Więcej o problematyce śmierci zob. J. Mossay, La mort et l'au-delà dans Saint Grégoire de Nazianze, Louvain 1966.

${ }^{87}$ Epistula 90 (Ad Procopium), PG 37, 164, POK 15, 122.

${ }^{88}$ Epistula 123 (Ad Theodorum), PG 37, 217, POK 15, 165.

${ }^{89}$ Epistula 124 (Ad Theodorum), PG 37, 217, POK 15, 165. 
„Módl się za mną - przyjmij moje postanowienie i, że się może niezgorzej wyrażę: zaprawiaj mnie do pobożności" $"$.

Kolejna prośba o modlitwę w tej samej sprawie, czyli o zdrowie, świadczy o zaufaniu Grzegorza do mocy modlitwy wstawienniczej. Ponadto można tu dostrzec inny aspekt w czasie przewlekłej choroby: cierpliwość w cierpieniu i w związku z tym kolejna prośba - o zaprawianie do pobożności.

Powrót do trwałego zdrowia musiał być istotną sprawą w życiu Grzegorza, skoro tak często o nim wspominał w prośbach o modlitwę w tej intencji. Biskup Ikonium, Amfilochiusz, również został wtajemniczony w ten egzystencjalny problem swego krewniaka, gdy odczytywał słowa: „Lecz, mój bracie zbożny, nie omieszkaj i modlić się i orędować za mną" "91. Nawet w liście do Nektariusza, biskupa Konstantynopola, dołączył prośbę o modlitwę, mimo że list dotyczy kwestii porządków prawnych pomiędzy władzą cywilną a kościelną. W końcowej części listu Grzegorz dodaje: „Módl się za mną - błagam - bo mnie srodze przyciska choroba"92. Powyższe prośby są dowodem na to, jak bardzo Kapadocczykowi zależało na tym szczególnym darze, którym jest zdrowie.

Grzegorz miewał chwile poprawy zdrowia, na co zwracają uwagę już wyżej zrelacjonowane fragmenty jego listów. Nie odzyskawszy jednak zdecydowanego powrotu do pełnego zdrowia, zaczął ujawniać, co można w jego korespondencji zauważyć, pewną rezygnację i dlatego prośby o modlitwę o zdrowie przekształcają się w prośby o dobrą śmierć. Wymieniony Helladiusz, który był przez Grzegorza poinformowany o swej chęci odejścia z tego świata, został przy tym poproszony także o modlitwę:

„Módl się za mnie, jeśli ci zależy na wyświadczeniu mi największego dobrodziejstwa" ${ }^{\prime 9}$.

Ta prośba jest bezpośrednim następstwem stwierdzenia o rychłym odejściu do Ziemi Obiecanej (zob. wyżej). Spełnienie tej prośby Grzegorz nazwał „największym dobrodziejstwem”, gdyż w dniach nasilenia się cierpienia i bólu uświadamiał sobie, że bliski jest koniec jego życia. Modlitewną prośbę o szczęśliwą śmierć Helladiusz otrzymał ponownie. I tę Grzegorz dołączył do pragnienia jego odejścia:

„Módl się za mną byś, jeśli to służy, znowu mi święto przypomniał i wzajem jak tobie, a jeśli nie - bym przeniesiony został tam i prawdziwe święto pojął czy ujrzał" $"$

Ta prośba nie tylko zakłada śmierć, lecz także odnosi się do szczęścia wiecznego, które Grzegorz pragnie posiąść - także za modlitewnym wsparciem bliskiego

\footnotetext{
${ }^{90}$ Epistula 139 (Ad Theodorum), PG 37, 237, POK 15, 181.

${ }^{91}$ Epistula 171 (Ad Amphilochium), PG 37, 280, POK 15, 212.

${ }^{92}$ Epistula 185 (Ad Nectarium), PG 37, 304, POK 15, 230.

${ }^{93}$ Epistula 120 (Ad Helladium), PG 37, 216, POK 15, 162.

${ }^{94}$ Epistula 172 (Ad Helladium), PG 37, 281, POK 15, 213.
} 
mu człowieka. Tymoteusz, bliżej nieznany adresat, w ostatnim zdaniu otrzymanego listu również został poproszony o modlitwę za kapadockiego biskupa:

„Módl się też za mną, srodze znużonym, bym miał spokojny odlot - ku temu już się mam!"’s

Ta wypowiedź ujawnia kondycję psychiczną Grzegorza: jest on już bardzo znużony, co oznacza, że jego wrażliwa dusza nie potrafi cieszyć się tym, co daje świat. Szykuje się raczej na spokojne odejście, na które jest już nastawiony, i prosi o modlitwę na ten ostatni akt życia.

Bardzo melancholijną refleksję Nazjanzeńczyk przesłał też do Grzegorza z Nyssy. Również w niej wartościuje ludzkie strapienia i zachęca do modlitwy:

„Modlimy się za siebie, póki jeszcze na ziemi jesteśmy - i oby nie rozłączył nas wspólny kres, ku któremu się zbliżamy. I dlatego powinniśmy wszystko cierpliwie znosić - bo ani radować się nie będziemy ani trapić zbyt długo"966.

Przytoczony tekst jest zakończeniem listu, w którym Grzegorz pociesza swego przyjaciela po stracie swej siostry Teozebii. Żałobny charakter listu pozwolił mu na wypowiedzenie istotnych uwag na temat prawideł rządzących kolejami ludzkiego losu. Doświadczony życiem stwierdza bowiem, że do wszystkiego wymagana jest cierpliwość, a radość ziemska i utrapienie kiedyś się skończą. Pokrzepieniem w tym może być wzajemna modlitwa, która jest możliwa tylko za życia na ziemi.

$* * *$

Dosyć pokaźna liczba wypowiedzi Grzegorza, zaczerpniętych z jego korespondencji, które wyżej zostały przytoczone, ujawnia jeden $\mathrm{z}$ wielu aspektów sylwetki Grzegorza z Nazjanzu. W literaturze badawczej jest on ukazywany jako wybitny teolog, retor, biskup, a nawet mistyk, który dokonał bardzo wiele dla ówczesnej ciągle rozwijającej się teologii. Niniejszy artykuł przedstawia Grzegorza jako starego człowieka ,z krwi i kości”, będącego w swym cierpieniu i chorobie kimś bliskim dla wielu innych strapionych życiowymi uciążliwościami. Ukazując siebie jako starca, stał się tym samym współbratem dla wszystkich starzejących się ludzi. Czytelnicy jego korespondencji, zarówno adresaci z IV wieku, jak i współcześni odbiorcy, mogą doznać szczególnego ukojenia, wnikając w duszę człowieka, który został wpisany w poczet świętych.

\footnotetext{
${ }^{95}$ Epistula 164 (Ad Timotheum), PG 37, 273, POK 15, 206.

${ }^{96}$ Epistula 197 (Ad Gregorium Nyssenum), PG 37, 324, POK 15, 242.
} 


\title{
REFLECTIONS ABOUT HIMSELF IN THE LETTERS \\ OF GREGORY OF NASIANSUS
}

\begin{abstract}
(Summary)
Beside his speeches and poems, Gregory of Nasiansus left 245 letters. Over 160 of them were written in the last decade of his life, when after two years of his work as a bishop in Constantinople he returned to the country where he grew up. An object of analysis in this article are his texts related to ageing, which was often described by him in his letters. Gregory was aware of his old age and ensuing consequences such as sickness, the need for silence, the awareness of approaching death and requests for prayer sent to addressees.

A number of passages taken from these letters reveal one of the many aspects of Gregory's silhouette. In majority of essays describing his person and output he is shown as an eminent theologian, a rhetorician, a bishop, and even a mystic, who contributed greatly to the development of the theology of that epoch. My article presents Gregory as a man of „flesh and blood", in his suffering and sickness very close to all subject to vicissitudes of life. Writing about himself as an elderly man, he became a brother of all ageing. The readers of his correspondence, both his addressees living in the fourth century and contemporary readers, may find a particular consolation in the experiences of the one recognized as a saint.
\end{abstract}

